\title{
Features of Teachers Preparedness to Work with Gifted Youth
}

\section{Akmaral Kulmagambetovna Satova}

\author{
Eurasian Academy of Law named after D.A. Kunaev; Email: satova57@mail.ru
}

\section{Doi:10.5901/mjss.2015.v6n5s3p45}

\begin{abstract}
The article is devoted to the experimental study of professional and personal preparedness of higher school teachers to work with gifted students. Thus, the presented materials indicate the need for the purposeful and systematic work on the formation of personal and professional preparedness of the higher school teachers to work with gifted students. It seems advisable to include section on the psychology of giftedness to content of the scientific and pedagogical training of undergraduates, that will allow to put into action more fully the intellectual and creative potential of all subjects of the educational process. Preparedness of teacher to work with gifted children and youth is defined as an integrative personal education consisting of motivational, substantial and procedural components.
\end{abstract}

Keywords: giftedness, personality, professional, personal preparedness of the teacher.

\section{Introduction}

From the point of view progressive scientific world, the humanity can avoid some global problems and continue the existence thanks to achievements of gifted and talented persons. Moreover, as V. Yurkevich notes, "... the prosperity of society depends on the development of spiritual, personal resources of the person, efficiency of the creation of creative space for the development of abilities of children, their creative and personal opportunities". Understanding of the power of human reason, its decisive influence on the development of civilization became the reason of increase of attention to training and education of gifted persons in the countries of America, Europe, Asia. Gifted and talented became one of the important factors of the definition of the position of the country on the world scene.

Expectations concerning results of activity of exceptional children have increased: from them wait for constructive development and the maximum return in different spheres of human endeavour that is source of requirements for scientists on creation of techniques of identification, ensuring effective development, training and education of gifted pupils.

The load of responsibility has laid down and on teachers: from them wait for high-quality actions in ensuring the development of abilities of pupils. Implementation of it is impossible without special preparation.

Proceeding from the above, it is possible to draw conclusion on need of global synthesis of science and practice because of which the corresponding strategy for forming of readiness of the teacher for work with exceptional children will be created.

Single organizational and methodical questions of training of teachers for work with gifted pupils reveal in the researches G. Tarasova; forming of readiness of pedagogical workers for training of gifted pupils in system of postdegree education is reflected in works of V. Demchenko, L. Makridin; A. Melnikova offered the psychological model of training of the teacher for work with exceptional children.

Researches of the personal qualities of the teacher promoting successful cooperation with exceptional children reveal D. Bogoyavlensky, A. Verkhozina, N. Leytes, I. Lyubovetskoy, J. Renzulli, K. Rogers, A. Khutorsky.

The phenomenon of endowments is the object of studying of A. Antonova, D. Bogoyavlensky, I. Voloschuk, M. Evtukh, E. llyin, V. Molyako, A. Savenkova, V. Shepotko and others.

The complexity of the organization of training for exceptional children is noted not by typicalness of approaches in each separate case. To provide algorithms of work with such pupils there is not enough, it is necessary that the teacher could adapt the received theoretical data for the gifted pupil. Definition of the optimum combination of the personal qualities, knowledge and abilities promoting the organization of teaching and educational process.

For the development of abilities, is the first-priority stage at the development of the system of training of the teacher for work with exceptional children. Therefore, the purpose of the article consists in the creation of a model of readiness of the teacher for work with gifted pupils. 
Training of teachers for work with gifted pupils has some unresolved tasks. Among those absence in science of uniform approach to understanding of phenomenon of endowments; absence of uniform requirements to the identity of the teacher for work with the exceptional child; lack of system of training of teachers in the direction of forming of theoretical knowledge; development of the corresponding practical skills and forming of the personal signs providing successful cooperation with gifted individuals.

Analyzing sources in which questions of readiness of teachers for work with exceptional children are considered, we come to the conclusion that most of the researchers consider it as system education. For example, the readiness of future mathematics teacher for training of gifted pupils is defined as difficult complete personal and efficient education. It requirements, abilities and professional abilities which provide creation of optimal conditions for development of potential mathematically of exceptional children in ways of the organization of particular psychology and pedagogical and methodical escort of the child that corresponds to his specific features, opportunities and requirements are part.

The projection of readiness of the pedagogical worker for training of the gifted individual is reflected through professional system quality of the teacher, which is determined by ability to effective implementation of professional activity, by creation of comfortable conditions for all-around, harmonious development of the exceptional child .

We offer the following option of approach to concept of readiness, namely readiness of the teacher for work with gifted pupils is considered as difficult quality education of complex of properties of the teacher which Cornerstone are his personal endowments, special knowledge, skills, internal motivation, certain traits of character which allow it to carry out at optimum and sufficient level search, development and implementation of abilities of pupils.

Generalizing stated, it is possible to characterize readiness of the teacher for work with gifted pupils as system of the psychology and pedagogical relations the subject - subject character which is aimed at the development of abilities of the gifted pupil and increase of professionalism of the teacher.

Proceeding from it, for the purpose of the definition of components of readiness the analysis of the existing models is carried out. For example, readiness of students of normal school for work with exceptional children is considered as system with such components: motivational (professionally significant pedagogical orientation, availability of pedagogical motivation), cognitive (ability to process information, development of the cognitive sphere, innovative thinking), operational (forming of abilities, skills of practical activities, mastering effective strategy of activity), emotional and strongwilled (dominance of positive "Ya-image", control of thoughts and feelings, mobilization of forces according to situation) .

In turn, L. Makridina suggests considering the readiness of the teacher for work with exceptional children as a system of motivational, cognitive, constructive, personal components.

Proceeding from the above, it is possible to make the conclusion that readiness of the teacher for cooperation with the gifted pupil is reflected in system, which promotes intellectual, creative, spiritual development of the child, and providing necessary conditions of training and education for implementation of the specified development. Creation of certain circumstances possibly at the related professional activity of the teacher, availability of necessary material resources for its implementation, support of the native. In turn, the efficiency of professional activity depends on the availability of the corresponding theoretical preparation. Still V. Zagvyazinsky noted that the knowledge of pedagogical laws is the basis of works of the teacher, without knowledge of the theory of training there is a danger of false creativity, amateurishness. It is also necessary to note that in pedagogical work in general and in work with exceptional children, in particular, the special role is played by special personal qualities of the teacher.

The carried-out analysis gives the chance to allocate the following components of readiness of the teacher for work with gifted pupils. Those are theoretical, practical and personal components. The next task consists in the definition of the structure of each element, considering that the teacher has received the corresponding preparation for pedagogical activity.

The basis of the theoretical component of readiness: the special pedagogical knowledge and knowledge from endowments area. As all-pedagogical knowledge of the teacher is gained in higher educational institutions, the system of preparation for work with gifted pupils has to be based on providing knowledge to them from endowments area. Expediency and optimality of theoretical knowledge will allow making the program compact and efficient.

\section{Methods and Materials}

The development strategy of our state until 2030 determines that the achievement of long-term goals in the development of Kazakhstan is possible only if the country has highly human intellectual potential with a high level of spiritual, scientific and creative development. Such potential determines the level of social and economic development of the state. That is exactly why the Constitution of the Republic of Kazakhstan guarantees to its citizens the repletion of wants of the individual in education and development. 
UNESCO Forecast indicates an increase in the number of students in the XXI century in the world to 100 million by 2025. This indicates a growing awareness of the vital role of higher education in ensuring sustainable economic and social development of the states, their security, strengthening positions in the international community and world markets, improving the level and quality of life of the population.

The formation of highly intelligent, proactive and creative personality of the graduate, the assistance in the sociocultural formation of talented young people is becoming the purpose of higher education (National Education Development Program of the Republic of Kazakhstan for 2011 - 2020).

One of the work intensification forms with gifted youth is a Presidential fund "Bolashak", functioning on the basis of the training program of the most gifted students in the leading higher education institutions in the world. However, this program is not able to provide conditions for the realization of the potential opportunities for all subjects of the educational process and each student. The leading role in the development of the gifted students' personality is assigned to higher schoolteachers.

The importance of personal and professional qualities of the teacher for successful work with gifted children and youth, with those young people who by their natural capabilities are ahead of their peers, does not raise doubts (L.M. Mitina, V.I. Panov, L. Popova, N.I. Scherbo, M. Lindsey, H. Passow, M. Carne et al.) (Panov, 1997; Carne, 1991; Carol Addison Takacs, 1986; Loseva, 1998 \& Psychology of giftedness: from theory to practice, 2000). "The concept of identification, support and development of gifted children in the Republic of Kazakhstan", "Working concept of giftedness" of the Russian Federation, as well as special training programs existing in the world of educational practice, have specific psychological and pedagogical requirements for teachers working with gifted children and youth. According to them, in the professional and personal qualifications of teachers for work with gifted young people it is possible to distinguish the following components:

- a basic component comprising vocational, general pedagogical training and professionally significant personal qualities of teachers;

- a specific component is comprising personal and professional preparedness to work with gifted children and youth.

In Kazakhstan, the studies on the issue of teacher preparedness to work with gifted children were performed by L.M. Narikbaeva, U.B. Zheksenbaeva, N.D. Ivanova, A.K. Satova (Narikbaeva, 2001 \& Zheksenbaeva, Ivanova \& Satova, 2005). They contained the basic guidelines for the content of this training. Based on the theories of personality, activity, professional preparedness, giftedness, professional education et al., preparedness of teachers to work with gifted children is defined as an integrative personal education consisting of motivational, substantial and procedural components.

In theory, the content of the abovementioned components can serve as a basis of the following criteria determining the personal and professional preparedness of the higher education institution teacher to work with gifted students:

a) Level of development of professional motivation, characterized by:

- the awareness of the social significance of the special work with gifted young people associated with a sharp increase in the society need for a personality with high creative and intellectual abilities;

- $\quad$ positive attitude to the ablest students, understanding of their psychological problems;

- steady interest and need to find effective means for work with gifted youth;

- the aspiration to achieve good results in work with gifted youth;

b) Academic level, characterized by:

- $\quad$ knowledge of subject content taught at a higher level than the State Standard of education;

- $\quad$ knowledge of theories of personality, creativity, and psychology of giftedness;

- knowledge of giftedness models and modern conceptual approaches to the development of the personality of gifted youth;

- knowledge of diagnostic techniques for identification of gifted youth;

- knowledge of modern pedagogical strategies for teaching gifted children and young people, the most effective, innovative educational technologies focused on the development of intellectual and creative potential of youth.

c) didactic level, characterized by:

- working knowledge of methods for identification of gifted young people;

- ability to draw up additional personal-oriented training programs for gifted students (group and individual);

- ability to pick up creative and research tasks and targets for the most capable students, etc.

In practical terms, the problem of teacher preparedness to work with gifted students require experimental studies.

The aim of our experiment was to determine the academic level of preparedness of the university teachers to work 
with gifted students. For this purpose, the test questionnaire consisting of 30 problematic issues revealing knowledge of the psychology of giftedness and modern conceptual approaches to the development of the identity of gifted youth was offered to teachers. 18 university professors took part in the survey.

\section{Results and Discussion}

Test classifier includes 3 levels of academic preparedness of teachers to work with gifted young people:

III - a low level of teacher preparedness to work with gifted children and youth. If you have more than a half of answers wrong, then you need to educate ourselves (or compose your own pedagogical theory). To work with gifted students is rather early to you.

II - a critical level of teacher preparedness to work with gifted children and youth. If you have only 5-7 wrong answers - it is quite good, in general, you feel the truth, you should only implement it in practice.

I - a sufficient level of teacher preparedness to work with gifted children and youth. If you have only 1-2 wrong answers, it is just great, you are a real talent, you have pedagogical intuition and you urgently need to find work that suits your remarkable teaching abilities.

Obtained results are shown in Table 1.

Table 1 - Levels of teachers preparedness to work with gifted students (abs. and in \%).

\begin{tabular}{|c|c|c|c|c|c|c|c|}
\hline \multicolumn{2}{|c|}{ Level 1 } & \multicolumn{2}{c|}{ Level 2 } & \multicolumn{2}{c|}{ Level 3 } & \multicolumn{2}{c|}{ Total } \\
\hline Abs. & $\ln \%$ & Abs. & $\ln \%$ & Abs. & $\ln \%$ & Abs. & $\operatorname{In} \%$ \\
\hline- & - & - & - & 18 & 100 & 18 & 100 \\
\hline
\end{tabular}

Thus, the obtained data indicate a low level of teachers' knowledge of the psychology of giftedness and modern conceptual approaches to the development of the identity of the gifted youth. The analysis of teachers answers shows that they have own, intuitive ideas about the nature of giftedness, its diagnostics, forms and methods of training and development of gifted students.

Such situation is caused by the fact that higher educational institutions of the Republic do not carry out special training of teachers to work with this category of students. At best, in the general psychology course future specialists get some idea about abilities. Work with gifted youth is touched in pedagogics course of the higher school simultaneously in connection with the study of the issues of education. The quantity of scientific-methodical literature on the identification, development, education of gifted students is not enough.

At the same time transition to a credit education system provides more and more favorable conditions for the differentiated and individual education of gifted students, and introduction of the personal-oriented technologies, interactive techniques contributes to the harmonization of their personal development, personal growth.

\section{Conclusion}

Thus, the presented materials indicate the need for the purposeful and systematic work on the formation of personal and professional preparedness of the higher schoolteachers to work with gifted students. It seems advisable to include section on the psychology of giftedness to content of the scientific and pedagogical training of undergraduates, that will allow to put into action more fully the intellectual and creative potential of all subjects of the educational process.

\section{References}

National Education Development Program of the Republic of Kazakhstan for 2011 - 2020

Panov, V.I. (1997) For teacher about gifted children (manual for teacher). M.: Young Guard. pp. 354.

Carne, M. (1991) Teacher. Chapter 4 / Gifted Children. Trans. from English. / Common. Ed. G.V. Burmenskaya and V.M. Slutsky. M. Carol Addison Takacs (1986) Enjoy Your Gifted Child. - New York.

Loseva, A.A. (1998) Work of the practical psychologist with gifted children of adolescence age // Journal of Practical Psychologist. № 3. pp. 84-87.

Psychology of giftedness: from theory to practice / Ed. Ushakova DV M.: IP RAS 2000. pp. 96.

Narikbaeva, L.M. (2001) Scientific and pedagogical bases of preparation of future teacher for work with gifted children. Author's abstract ... Cand. of pedagogic sciences. Almaty.

Zheksenbaeva, U.B., Ivanova N.D. and Satova A.K. (2005) Special course program "Formation of professional and personal preparedness of teachers to work with gifted children". Almaty. pp. 28. 